1998年 日本熱帯生態学会シンポジウムの記録 特集

\title{
公開シンポジウム「ホルネオの自然と人間」
}

\section{Nature and People in Borneo}

(於＼cjkstart札幌市＼cjkstart北海道大学学術交流会館)

\author{
はじめに \\ 田川日出夫（鹿児島県立短期大学） \\ Hideo TAGAWA (Kagoshima Prefectural College) \\ 甲山 隆司 (北海道大学大学院地球環境科学研究科) \\ Takashi KOHYAMA (Graduate School of Environmental \\ Earth Science, Hokkaido University)
}

本特集は, 1998 年6月 21 日に, 北海道大学学術交流会館で開催された日本熱帯生態学会第 8 回 年次大会公開シンポジウム『ボルネオの自然と人間』のプロシーディングズである。シンポジウ ムの目論見は, ボルネオ島という本学会にとってもなじみ深い場を対象として, 際立った生物多 様性・環境特性から人間社会の特性までを含む多面的な切り口から, 对象を構造的に把握するこ とにあった。

ボルネオ島では, 1981 年に宮脇昭らの東カリマンタンの熱帯多雨林とその二次林に関する植 物社会学的 調査が行われ, 1985 年に山倉らによる東カリマンタンのフタバガキ林の調査, 田川 らによって 1986 年以降, 東カリマンタン・クタイ国立公園における 1992 - 93 年の森林火災に よる被災多雨林の自然回復過程についての研究などが行われている。現在では文 部省科学研究 費だけでなく, 環境庁の地球環境研究総合推進費などによって, いくつかの大型の熱帯多雨林の 生態学プロジェクトが進行している。特にマレーシア・サラワク州北東部ミリ市近郊のランビル ヒルズ国立公園やサバ州キナバル山国立公園では, 1990 年代前半から本学会員を中心とする日 本の研究グループが, 現地研究者らと共同して, 生物多様性の維持や地球環境変化への応答に注 目した大型プロジェクトを展開しており, 若手研究員・大学院生が常駐する体制の整った生態観 測ステーションから, 多くの重要な成果があがりつつある。

このような大型プロジェクトによるステーションからの知見が累積されていく一方で，いまだ この広大な島の自然と生態についての全体像を把握するには程遠いのも事実である。熱帯多雨林 の構成要素で重要な生物資源でもある樹木相の把握とマニュアル化という基本的なプログラムひ とつをとってみても, 林業実務者を対象としてマレーシア森林研究所から刊行されたマレー半島 の樹木誌 Tree Flora of Malaya (1972 1989) に対応する Tree Flora of Sabah and Sarawak の刊 行は 1995 年から始まったところで, インドネシア領をカバーする Tree Flora of Kalimantan の 刊行計画はチェックリストが一度整理された段階で頓挫している。ボルネオ島の際立った樹木相 
多様性が急速に変容しつつある現状に，プログラムが追いついていないことがよくわかる。 本シンポジウムの前年には地球規模の気候現象により, ボルネオ島の多雨林は長期間の乾燥に さらされ, 焼き畑火入れの延焼による火災と煙害が深刻な社会問題となったことは記憶にあたら しい。焼き畑耕作可能地の拡大は, 政府による大規模なプランテーション・農耕地開発計画によ る道路敷設に密接に関係しており, 災害が自然と人間社会の複合構造を背景にしていることはあ きらかである。

こうした自然と人間のフィードバック系としてのボルネオ島を把握するためには，狭義の生態 学でなく, 多元的な視野を持つ必要がある。本学会の意図する熱帯生態学の領域でもある, こう した広域を対象とした多元的な話題提供を企図して, このシンポジウムでは, 森林生態学, 水文 気象学, 土㗒学, そして社会生態学の各領域から, 自然と人間の営みを考察する計画とした。期 せずして, マレーシア領のサバ州・サラワク州およびブルネイの行政域になる北西ボルネオでな く, 同島の $2 / 3$ を占めるインドネシア領のカリマンタン諸州が主な考察の対象とされた。樹木に みる種多様性および生活特性多様性の実態 (鈴木英治), ボルネオ島低地に卓越する内陸性泥炭 湿地の物理環境特性 (高橋英紀), 基岩と地形に起因する土壌・植生系の多様性と農業土地利用 (櫻井克年), ボルネオと外界との人と生態資源のフラックス (山田勇), 東カリマンタンからの 森林火災被害の詳細な解析 (藤間剛), そして大規模開発計画にともなう土地利用形態の急速な 変容の把握（佐々木英之）と, 各領域から透徹したレビューが報告された。本特集では, 限られ た講演時間のために省略された部分・内容についてもさらに掘り下げた論文にまとめられている ので, とりわけボルネオを研究する者にとって貴重なテキストとなっている。

ボルネオの自然と人間社会の対照性のなかでも際立ったものに, 自然生態系としての熱帯多雨 林の高生物量蓄積・高生産力・高種多様性に対する, 農耕生態系のぜい弱性・貧栄養性・低生産 性が挙げられるだろう。豊かな熱帯多雨林というイメージは人間活動が介在する系にはあてはま らないのだろうか。高い種多様性は比較的低い栄養環境下であらわれるという説明があるが，そ うした観点から, 熱帯域の高生物多様性は, 同域の低農業生産性とおなじく熱帯土境の貧栄養性 で説明できる，との極論まで提出されている (M. A. Huston, 1995, Biological Diversity : The Coexistence of Species on Changing Landscapes, Cambridge Univ. Press)。熱帯環境では生き ている植物部分に保持される栄養が多いシステムだし, 気候的な高生産環境を生かした自然のシ ステムが成り立っていることを否定する必要まではないだろう。農耕系ではそうした持続的な高 生産性が再現されずにいるとすれば，それはなぜだろうか。本特集のテキストのなかに提供され ている多くの手掛かりから，こうした問題にも答えていくことができるように思われる。

企画を上回る内容のシンポジウムと特集となったことについて, 話題提供者のみなさんにお礼 申しあげたい。ランビルヒルズ国立公園の林冠プロジェクトのリーダー井上民二さんに甲山が本 シンポジウム計画について電話で相談して助言いただいたのは, 最後となつたボルネオへの旅立 ちの前日だった。この特集を見ていただけないのが残念である。 